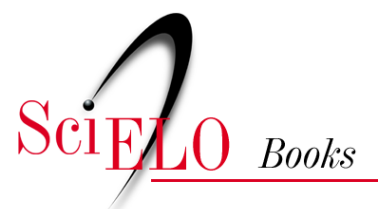

\title{
8. Fundamentos ético-políticos da educação no Brasil de hoje
}

\author{
Antônio Joaquim Severino
}

\section{SciELO Books / SciELO Livros / SciELO Libros}

SEVERINO, A.J. Fundamentos ético-políticos da educação no Brasil de hoje. In: LIMA, J.C.F., and NEVES, L.M.W., org. Fundamentos da educação escolar do Brasil contemporâneo [online]. Rio de Janeiro: Editora FIOCRUZ, 2006, pp. 289-320. ISBN: 978-85-7541-612-9. Available from: doi: 10.7476/9788575416129.0010. Also available in ePUB from: http://books.scielo.org/id/j5cv4/epub/lima-9788575416129.epub.

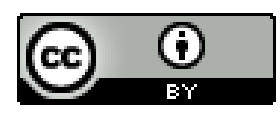

All the contents of this work, except where otherwise noted, is licensed under a Creative Commons Attribution $\underline{4.0 \text { International license. }}$

Todo o conteúdo deste trabalho, exceto quando houver ressalva, é publicado sob a licença Creative Commons Atribição 4.0. 


\title{
8. Fundamentos Ético-Políticos da Educação no Brasil de Hoje
}

Antônio Joaquim Severino

\begin{abstract}
A educação é processo inerente à vida dos seres humanos, intrínseco à condição da espécie, uma vez que a reprodução dos seus integrantes não envolve apenas uma memória genética mas, com igual intensidade, pressupõe uma memória cultural, em decorrência do que cada novo membro do grupo precisa recuperá-la, inserindo-se no fluxo de sua cultura. Ao longo da constituição histórico-antropológica da espécie, esse processo de inserção foi se dando, inicialmente, de forma quase que instintiva, prevalecendo o processo de imitação dos indivíduos adultos pelos indivíduos jovens, nos mais diferentes contextos pessoais e grupais que tecem a malha da existência humana. Porém, com a 'complexificação' da vida social, foram implementadas práticas sistemáticas e intencionais destinadas a cuidar especificamente desse processo, instaurando-se então instituições especializadas encarregadas de atuar de modo formal e explícito na inserção dos novos membros no tecido sociocultural. Nasceram então as escolas.

Sem prejuízo dos esforços e investimentos sistemáticos que ocorrem no seio de suas práticas formais, o processo abrangente de educação informal continua presente e atuante no âmbito da vida social em geral, graças às atividades interativas da convivência humana. Mas a formalização cada vez maior da interação educativa decorre da própria natureza da atividade humana, que é sempre intencionalmente planejada, sempre vinculada a um télos que a direciona. Desse modo, todos os agrupamentos sociais, quanto mais se tornaram complexos, mais desenvolveram práticas formais de educação, institucionalizando-as sistematicamente.
\end{abstract}


Desde sua gênese mais arcaica, essa inserção sociocultural envolve sempre uma significação valorativa, ainda que o mais das vezes implícita nos padrões comportamentais do grupo e inconsciente para os indivíduos envolvidos, pois se trata de um compartilhamento subjetivamente vivenciado de sentidos e valores. A cultura, como conjunto de signos objetivados, só é apropriada mediante um intenso processo de subjetivação.

O existir histórico dos homens realiza-se objetivamente nas circunstâncias dadas pelo mundo material (a natureza física) e pelo mundo social (a sociedade e a cultura) como referências externas de sua vida. No entanto, essa condição objetiva de seu existir concreto está intimamente articulada à vivência subjetiva, esfera constituída de diferentes e complexas expressões de seus sentimentos, sensibilidades, consciência, memória, imaginação. Esses processos põem em cena a intervenção subjetiva dos homens no fluxo de suas práticas reais, marcando-as intensamente. Mas, ao mesmo tempo, as referências objetivas condicionantes da existência atuam fortemente na gestação, na formação e na configuração dessa vivência. Daí falar-se do processo de subjetivação, modo pelo qual as pessoas constituem e vivenciam sua própria subjetividade. A percepção dos valores integra esse processo tanto quanto a intelecção lógica dos conceitos. Esse processo de subjetivação é que permite aos homens atribuir significações aos dados e situações de sua experiência do real, o que eles fazem sempre de forma plurivalente, pois essa atribuição de significações não leva a sentidos unívocos, porém, o mais das vezes, plurais e mesmo equívocos.

A discussão dos fundamentos ético-políticos da educação, objeto desta reflexão, envolve necessariamente a esfera da subjetivação, uma vez que implica referência a valores. Para conduzir essa discussão, o presente ensaio, elaborado de uma perspectiva filosófico-educacional, foi desenvolvido em três movimentos, cada um deles se desdobrando em dois percursos. O primeiro movimento, de caráter antropológico, procura, no primeiro percurso, situar a educação como prática humana, mediada e mediadora do agir histórico dos homens; e, no segundo, fundamentar teoricamente a necessária intencionalidade ético-política dessa prática, explicitando a sua relação com o processo de subjetivação. No segundo movimento, de cunho histórico, busca-se no primeiro momento mostrar como a experiência socioeducacional brasileira marcou-se por diversas subjetivações ideológicas, enquanto no segundo são destacados, por sua relevância, os desafios e dilemas da educação brasileira atual no contexto da sociabilidade neoliberal. No terceiro movimento, que tem uma perspectiva político- 
pedagógica, ressalta-se, inicialmente, o compromisso ético-político da educação como mediação da cidadania, para enfatizar, em seguida, a importância que a escola pública ainda tem como espaço público privilegiado para um projeto de educação emancipatória.

\section{A Educação como Prática Histórico-Social}

Falar de fundamentos éticos e políticos da educação pressupõe assumila na sua condição de prática humana de caráter interventivo, ou seja, prática marcada por uma intenção interventiva, intencionando mudar situações individuais ou sociais previamente dadas. Implica uma eficácia construtiva e realiza-se numa necessária historicidade e num contexto social. Tal prática é constituída de ações mediante as quais os agentes pretendem atingir determinados fins relacionados com eles próprios, ações que visam provocar transformações nas pessoas e na sociedade, ações marcadas por finalidades buscadas intencionalmente. Pouco importa que essas finalidades sejam eivadas de ilusões, de ideologias ou de alienações de todo tipo: de qualquer maneira são ações intencionalizadas das quais a mera descrição objetivada obtida mediante os métodos positivos de pesquisa não consegue dar conta da integralidade de sua significação. O lado visível do agir educacional dos homens fica profundamente marcado por essa construtividade e historicidade da prática humana e, como tal, escapa da normatividade nomotética e de qualquer outra forma de necessidade, seja ela lógica, seja biológica, física ou mesmo social, se tomado este último aspecto como elemento de pura objetividade. Os fenômenos de natureza política e educacional não se determinam por pura mecanicidade, ou melhor, só a posteriori ganham objetividade mecânica, transitiva, mas, a essa altura, já perderam sua significação especificamente humana. É que eles se dão num fluxo de construtividade histórica, construção esta referenciada a intenções e finalidades que comprometem toda a logicidade nomotética de seu eventual conhecimento.

O caráter práxico da educação, ou seja, sua condição de prática intencionalizada, faz com que ela fique vinculada a significações que não são da ordem da fenomenalidade empírica dessa existência e que devem ser levadas em conta em qualquer análise que se pretenda fazer dela, exigindo diferenciações epistemológicas que interferem em seu perfil cognoscitivo. Educação é prática histórico-social, cujo norteamento não se fará de maneira técnica, con- 
forme ocorre nas esferas da manipulação do mundo natural, como, por exemplo, naquelas da engenharia e da medicina.

No seu relacionamento com o universo simbólico da existência humana, a prática educativa revela-se, em sua essencialidade, como modalidade técnica e política de expressão desse universo, e como investimento formativo em todas as outras modalidades de práticas. Como modalidade de trabalho, atividade técnica, essa prática é estritamente cultural, uma vez que se realiza mediante o uso de ferramentas simbólicas. Desse modo, é como prática cultural que a educação se faz mediadora da prática produtiva e da prática política, ao mesmo tempo que responde também pela produção cultural. É servindo-se de seus elementos de subjetividade que a prática educativa prepara para o mundo do trabalho e para a vida social (Severino, 2001). Os recursos simbólicos de que se serve, em sua condição de prática cultural, são aqueles constituídos pelo próprio exercício da subjetividade, em seu sentido mais abrangente, sob duas modalidades mais destacadas: a produção de conceitos e a vivência de valores. Conceitos e valores são as referências básicas para a intencionalização do agir humano, em toda a sua abrangência. O conhecimento é a ferramenta fundamental de que o homem dispõe para dar referências à condução de sua existência histórica. Tais referências se fazem necessárias para a prática produtiva, para a política e mesmo para a prática cultural.

Ser eminentemente prático, o homem tem sua existência definida como um contínuo devir histórico, ao longo do qual vai construindo seu modo de ser, mediante sua prática. Essa prática coloca-o em relação com a natureza, mediante as atividades do trabalho; em relação com seus semelhantes, mediante os processos de sociabilidade; em relação com sua própria subjetividade, mediante sua vivência da cultura simbólica. Mas a prática dos homens não é uma prática mecânica, transitiva, como o é a dos demais seres naturais; ela é uma prática intencionalizada, marcada que é por um sentido, vinculado a objetivos e fins, historicamente apresentados.

Além disso, a intencionalização de suas práticas também se faz pela sensibilidade valorativa da subjetividade. O agir humano implica, além de sua referência cognoscitiva, uma referência valorativa. Com efeito, a intencionalização da prática histórica dos homens depende de um processo de significação simultaneamente epistêmico e axiológico. Daí a imprescindibilidade das referências éticas do agir e da explicitação do relacionamento entre ética e educação. 


\section{A Prática Educacional como Prática ÉTICO-POLÍTICA}

Na esfera da subjetividade, a vivência moral é uma experiência comum a todos nós. Pelo que cada um pode observar em si mesmo e pelo que se pode constatar pelas mais diversificadas formas de pesquisas científicas e de observações culturais, todos os homens dispõem de uma sensibilidade moral, mediante a qual avaliam suas ações, caracterizando-as por um índice valorativo, o que se expressa comumente ao serem consideradas como boas ou más, lícitas ou ilícitas, corretas ou incorretas. Hoje se sabe, graças às contribuições das diversas ciências do campo antropológico, que muitos dos padrões que marcam o nosso agir derivam de imposições de natureza sociocultural, ou seja, os próprios homens, vivendo em sociedade, acabam impondo uns aos outros determinadas normas de comportamento e de ação. Mas a incorporação dessas normas pressupõe uma espécie de adesão por parte das pessoas individualmente, ou seja, é preciso que elas vivenciem, no plano de sua subjetividade, a força do valor que lhe é, então, imposto. Os usos, os costumes, as práticas, os comportamentos, as atitudes que carregam consigo essas características e que configuram $\mathrm{o}$ agir dos homens nas mais diferentes culturas e sociedades constituem a moral. A moralidade é fundamentalmente a qualificação desses comportamentos, aquela 'força' que faz com que eles sejam praticados pelos homens em função dos valores que essa qualificação subsume. Podemos constatar que é em função desses valores que as várias culturas, nos vários momentos históricos, vão constituindo seus códigos morais de ação, impondo aos seus integrantes um modo de agir que esteja de acordo com essas normas. Porém, por mais que se encontre premido por essas normas, o homem defronta-se com a experiência insuperável de que participa pessoalmente da decisão que o leva a agir dessa ou daquela maneira; sente-se responsável por sua ação e muitas vezes bem ciente das conseqüências dela. Assim, a norma moral tem um caráter imperativo que o impressiona. Os valores morais impõem-se ao homem com força normativa e prescritiva, quase que ditando como e quando suas ações devem ser conduzidas. Quando não as segue, tem a impressão de estar fazendo o que não devia fazer, embora continue com um nível proporcional de liberdade para não fazer como e quando a norma parece lhe impor.

Se toda e qualquer ação do homem dependesse deterministicamente de fatores alheios à sua vontade livre, então não seria o caso de se sentir responsá- 
vel por elas; mas ocorre que, apesar de toda a gama de condicionamentos que o cercam e o determinam, há margem para a intervenção de uma avaliação de sua parte e para uma determinada tomada de posição e de decisão. Goza, por isso, de um determinado campo de liberdade, de vontade livre, de autonomia, não podendo alegar total determinação por fatores externos à sua decisão.

Hoje, os conhecimentos objetivos da realidade humana, proporcionados pelas ciências humanas, de modo especial a psicologia, a sociologia, a economia, a etologia, a psicanálise, a antropologia e a história, permitem identificar com bastante precisão aquelas atitudes que são tomadas por imposição de forças superiores à vontade pessoal. Mas permitem ver igualmente mais claro o alcance da vontade e o nível de arbítrio de que se dispõe quando se tem de escolher entre várias alternativas, assim como a possibilidade de saber qual a 'melhor' opção cabe em cada caso. Pode-se falar então da consciência moral, fonte de sensibilidade aos valores que norteiam o agir humano, análoga à consciência epistêmica, que permite ao homem o acesso à representação dos objetos de sua experiência geral, mediante a formação de conceitos. Assim, como tem uma consciência sensível aos conceitos, tem igualmente uma consciência sensível aos valores.

Do mesmo modo que a filosofia sempre se preocupou em discutir e buscar compreender como se formam os conceitos, como se pode acessá-los, o que os funda, ela procura igualmente compreender como se justifica essa sensibilidade aos valores. Desenvolveu então uma área específica de seu campo de investigação, no âmbito da axiologia, para conduzir essa discussão: a ética.

Cabe aqui um breve esclarecimento semântico. Moral e ética não são propriamente dois termos sinônimos, apesar da etimologia análoga, em latim e em grego, respectivamente. É certo que, na linguagem comum do dia-a-dia, já não se distingue um conceito do outro. Mas, a rigor, moral refere-se à relação das ações com os valores que a fundam, tais como consolidados num determinado grupo social, não exigindo uma justificativa desses valores que vá além da consagração coletiva em função dos interesses imediatos desse grupo. No caso da ética, refere-se a essa relação, mas sempre precedida de um investimento elucidativo dos fundamentos, das justificativas desses valores, independentemente de sua aprovação ou não por qualquer grupo. Por isso, fala-se de ética em dois sentidos correlatos: de um lado, frisa-se a sensibilidade aos valores justificados mediante uma busca reflexiva por parte dos sujeitos; de outro, convencionou-se chamar igualmente de ética a disciplina filosófica que busca elucidar esses fundamentos. 
Mas de onde vem o valor dos valores? Onde se funda a consciência moral? Se o homem é um ser histórico em construção, em devir, sem vinculação determinante com a essência metafísica e a natureza física, naquilo que lhe é específico, onde ancorar a referência valorativa de sua consciência moral? $O$ valor fundador dos valores que fundam a moralidade é aquele representado pela própria dignidade da pessoa humana, ou seja, os valores éticos fundam-se no valor da existência humana. É em função da qualidade desse existir, delineado pelas características que lhe são próprias, que se pode traçar o quadro da referência valorativa, para se definir o sentido do agir humano, individual ou coletivo. O próprio homem já é um valor em si, nas suas condições contingenciais de existência, na sua radical historicidade, facticidade, corporeidade, incompletude e finitude.

Assim, a filosofia, por meio da ética, busca dar conta dos possíveis fundamentos desse nosso modo de 'vivenciar' as coisas, tendo sempre em vista que é necessário ir além das justificativas imediatistas, espontaneístas e particularistas das morais empíricas de cada grupo social. A ética coloca-se numa perspectiva de universalidade, enquanto a moral fica sempre presa à particularidade dos grupos e mesmo dos indivíduos. Mas é possível encontrar um fundamento universal para os valores éticos? A filosofia ocidental, como mostra sua história milenar, sempre o procurou e continua a procurá-lo, dada a permanência das demandas da consciência ética.

\section{A EducaçÃo BrasileIRA: DETERMINAÇÃo hISTÓRICA E SUBJETIVAÇÃO VALORATIVA}

A presença da educação formal e institucionalizada é traço marcante das sociedades ocidentais, com destaque para a sociedade européia. No caso do Brasil, em que pese sua ainda pequena trajetória na era moderna da sociedade ocidental e a lentidão de seu desenvolvimento nos três primeiros séculos de sua inserção histórica nessa sociedade, ela não ocorreu de forma diferente. O Brasil conta com uma já bastante visível experiência de educação formal, experiência esta herdeira da experiência européia, forjada sob a marca da perspectiva cristã, mas tributária igualmente das circunstâncias históricas próprias do contexto local.

Instaurada então nos idos da fase colonial sob a concepção escolástica da formação humana, a educação no Brasil nasce como obra do trabalho missionário dos jesuítas, fundada sob uma perspectiva ideológica católica, de origem 
na Contra-Reforma, e operacionalizada pedagogicamente sob o modelo da escolástica. Em que pese a pequena expressão de um aparelho escolar nesse período, a cultura brasileira dos períodos colonial e imperial foi impregnada pelo catolicismo. Com seus conceitos e valores, o catolicismo marcou a vida social e cultural do país, contribuindo significativamente para um forte processo de subjetivação de seus habitantes, sob a representação dos dogmas doutrinários católicos.

No que concerne às relações entre a educação e a ideologia católica, fundada, de um lado, na teologia cristã e, de outro, na metafísica da escolástica tomista, prevalece a postulação de uma ética essencialista, articulada ao voluntarismo moral. A dimensão política não tem autonomia como dinâmica de pulsão de valores propriamente sociais. Toda a defesa dos valores cristãos é baseada na crença do poder da vontade individual para a condução da vida, uma vez que da postura ética de todas as pessoas decorreria necessariamente uma vida coletiva harmoniosa, independentemente das condições contextuais, da hierarquização das pessoas e da arbitrariedade das ações dos mais fortes. Não sem razão, durante todo esse longo período de Colônia e Império, a evolução do sistema educacional do país, tanto do ponto de vista organizacional como do ponto de vista de sua função social, foi pouco significativa, uma vez que a finalidade da escola encontrava-se na continuidade da finalidade evangelizadora e pastoral da Igreja, não se podendo falar de referências políticas para a configuração da ética. Visava-se a uma ética fundada na vontade individual das pessoas, o que podia se realizar preferencialmente na esfera privada, não se atribuindo à educação a contribuição para a instauração de um espaço público de vida. Desse modo, o pouco que houve de institucionalização de educação escolar serviu de reforço para a reprodução da ideologia dominante e das condições econômico-sociais, marcadas pela degradação, pela opressão e pela alienação da maioria da população em relação às situações de trabalho, de participação política e de vivência cultural. O modelo econômico era o agrárioexportador, voltado para a produção agrícola destinada à exportação aos países centrais. Todo o aparato político da época visava dar sustentação aos segmentos dominantes, que, além de possuírem os meios de produção e até a força de trabalho (detinham a posse da terra, a força escrava, a renda financeira), utilizavam o controle ideológico pela divulgação e 'inculcação' da concepção cristã do mundo. Assim, ao lado da alienação objetiva em que as pessoas se encontravam lançadas pelas condições socioeconômicas, ocorria o reforço de 
uma percepção enviesada dessas condições pela consciência, que instaura então uma alienação subjetiva. Coube ao ideário católico exercer esse papel, funcionando então como ideologia adequada ao momento histórico.

Pode-se afirmar que o cristianismo, a par de seus princípios teológicos, apresentava igualmente uma ética individual, da qual decorreram as referências também para o convívio social, dada a suprema prioridade da pessoa sobre a sociedade. É a qualidade moral dos indivíduos que devia garantir a qualidade moral da sociedade. Mas o caráter idealizado dessas referências comprometia sua eficácia histórica, pois esta dependeria da causalidade da vontade, insuficiente para mover a realidade social. Daí transformar-se numa ideologia, atuando apenas como ideologia. É o que explica sua incapacidade de impedir a prática da escravidão, apesar de, no plano teórico, tratar-se de prática incompatível com os valores apregoados.

Mas a ideologia católica dos primeiros séculos de formação da sociedade brasileira foi perdendo aos poucos sua hegemonia em decorrência da mudança socioeconômica pela qual o país igualmente sofreu em decorrência da lenta, extensa e intensa expansão do capitalismo. Embora a imersão do Brasil no capitalismo não tivesse ocorrido com características idênticas ao que havia acontecido na Europa e na América do Norte, não se podendo nem mesmo falar de uma revolução burguesa que o implantasse em nossas paragens, o país não podia escapar à influência dessa expansão comandada inicialmente pelos ingleses e, posteriormente, pelos americanos. Assim, a sociedade brasileira, embora conservando muitos elementos de sua fase escravista, incorporou as forças produtivas do modo de produção capitalista e as conseqüentes configurações no plano político e cultural. Da mesma forma, novos valores passaram a marcar a subjetividade das pessoas, dando nova fisionomia à vida da sociedade. Com o capitalismo, a oligarquia rural e o campesinato perderam poder social, emergindo uma burguesia urbano-industrial, as camadas médias e o proletariado, que se tornaram os novos sujeitos a conduzir a vida nacional, impondo alterações significativas no perfil da vida político-social do país. Em que pesem suas reconhecidas limitações, o processo republicano espelhou essa nova realidade, ligando-se a novas referências ideológicas, decorrentes de outros paradigmas filosóficos, como o iluminismo, o liberalismo, o laicismo, o positivismo (Severino, 1986).

A nova ideologia que se configurou entrou em conflito com a ideologia conservadora do catolicismo, embora se trate de conflito que não chegou a 
gerar uma ruptura radical na coesão da sociedade, em função das peculiaridades da própria configuração das classes sociais do país. A Revolução de 1930 é um marco representativo desse novo momento vivido pela sociedade brasileira, referendando-o e dando-lhe maior identidade. O processo se consolidou com o fim da Segunda Guerra Mundial, quando o capitalismo, sob a égide americana, se instalou de forma irreversível. Com a Revolução de 1964, esse ciclo se completou, mediante uma estruturação tecnocrática, inserindo de vez a economia do país no fluxo do capitalismo mundial.

Essa modernização econômica e cultural do país levou à paulatina substituição da ideologia religiosa do catolicismo por uma ideologia laica, de inspiração liberal e republicana. Nesse novo ambiente de desenvolvimentismo e modernização, a educação institucionalizada teve seu papel extremamente revalorizado, uma vez que lhe cabiam então tarefas importantes não só na formação cultural das pessoas mas também na profissionalização dos trabalhadores para as indústrias e para os diversos serviços. Além disso, as camadas médias viam na educação um dos principais caminhos para a ascensão social, o que suscitou forte demanda pela educação. Esta deveria ser fornecida por um sistema público, laico, imune às interferências de cunho religioso. À educação cabia então cuidar da preparação de mão-de-obra para a expansão industrial e dos serviços, bem como da oferta de cultura e status social. Este passava a ser o perfil do novo cidadão, imbuído de espírito público e identificado com a construção de sua pátria nacional.

Todo o complexo conjunto de valores, de forte inspiração iluminista e liberal, passou a ganhar contornos específicos, constituindo uma nova hegemonia ideológica. O modelo academicista, literário e humanístico da educação cristã foi considerado alienado em relação aos problemas sociais do país e não tinha condições de superar os desafios do atraso nacional. Só um humanismo lastreado no conhecimento científico e expresso mediante valores liberais poderia levar o país a seu verdadeiro destino. E a educação pública era o grande instrumento de que dispunha a sociedade para alcançar esse objetivo. Pública, laica, obrigatória e gratuita, a nova educação, nascida no bojo de uma reconstrução educacional, seria a única via para a reconstrução social. São apregoados os valores ligados ao espírito científico, à ordem democrática, às metodologias renovadas de ensino, à esfera pública, à cidadania e ao desenvolvimento econômico e social do país.

Mas esse novo projeto encontrou dois obstáculos insuperáveis que fizeram com que esses novos valores continuassem sendo apenas valores ideológi- 
cos. De um lado, a ideologia religiosa do catolicismo, embora não mais hegemônica no plano oficial, continuou impregnando, capilarmente, a vida cultural brasileira, da qual constitui, na verdade, uma camada arcaica da subjetivação das massas, arraigada que era no espírito do povo - e, como tal, impôs resistência à recepção das novas referências. Por isso, o impacto da nova ideologia, do lado da subjetivação, foi muito lento e superficial. De outro lado, o modo de produção capitalista tem suas exigências férreas, suas cláusulas pétreas, e não atua nos termos dos valores que apregoa. As políticas educacionais e culturais efetivamente implementadas não foram necessariamente coerentes, em seu caráter radical, com os valores declarados. Com isso, não se nega o efetivo desenvolvimento ocorrido no país, mas ele não aconteceu por força da realização dos novos valores; ao contrário, ocorreu muito mais pela violência das determinações do capitalismo em sua incansável busca da acumulação, com sensibilidade mínima às necessidades objetivas da maioria da população.

De qualquer modo, é correto afirmar que a ideologia que prevaleceu como elemento aglutinador da constituição da subjetividade social brasileira desse segundo período da trajetória sociopolítico-educacional do país foi a ideologia liberal burguesa, laicizada, modernizada e modernizadora, com pretensão de ser fundada na ciência e no reconhecimento da liberdade e da igualdade humanas. Impôs-se assim uma concepção liberal do mundo, da cultura e da educação. Essa ideologia atendia aos interesses da burguesia nacional urbanoindustrial e justificava a modernização de todos os setores da vida social. $\mathrm{Na}$ verdade, estava lançando raízes para um projeto que deveria consolidar cada vez mais o capitalismo monopolista, a serviço do qual deveria ser colocado o próprio Estado (Bresser Pereira, 1968; Fernandes, 1975).

No entanto, assim como a ideologia católica, a ideologia liberal não conseguiu implementar uma educação efetivamente voltada para a emancipação de toda a população, como pressupunha o ideário republicano, liberal e iluminista, limitando-se a exercer apenas seu papel ideológico, ou seja, proclamar, como se fossem universais, valores que são realizados apenas para atender a interesses particulares de grupos privilegiados. Enquanto as camadas dominantes mantiveram e ampliaram seus privilégios e as camadas médias usufruíram de algumas conquistas, vendo atendidas algumas de suas reivindicações, graças a seu poder de negociação e de aliança, os segmentos populares alcançaram objetivamente poucas conquistas econômicas, sociais e culturais, aí incluída a educação, que sequer se universalizou em seus níveis iniciais. 
Apesar de o atendimento das necessidades do povo fazer parte explícita do discurso político oficial, como se fosse o objetivo primordial das políticas públicas, na realidade, no tecido socioeconômico, não ocorreram mudanças significativas, nem quanto à quantidade nem quanto à qualidade. É o que mostram a injusta distribuição não só da renda como também dos bens culturais e os índices da desigualdade social, que permanecem até hoje (IBGE, 2005).

Agregou-se a essa ideologia liberal a crença no caráter redentor e equalizador da educação, que, se fosse difundido universalmente, eliminaria os conflitos de classe, promoveria o progresso econômico e social e asseguraria a condição de cidadania a todas as pessoas (Xavier, 2005).

Com o regime militar autoritário que se estabelece no país em 1964, os elementos básicos dessa concepção socioeducacional foram mantidos tecendo a política educacional, mas agregando agora um referencial a mais, que é aquele do valor técnico especializado da educação. Essa peculiaridade dará às políticas públicas do período e, em particular, às políticas educacionais um feitio explicitamente tecnicista sob uma perspectiva ideológica tecnocrática. Foi característica do movimento conduzido pela elite empresarial e pelo estamento militar a idéia-força de que o desenvolvimento tecnológico é a grande matriz de todo desenvolvimento econômico, desde que possa ocorrer num clima de total harmonia político-social. Daí ser a educação chamada a implementar uma vocação eminentemente dedicada à formação profissional, visando à preparação de mão-de-obra técnica bem qualificada de cidadãos ordeiros e pacíficos. Foi imbuído desse espírito que o próprio mote do novo sistema de gerenciamento da nação se expressou, retomando o anacrônico lema comtiano 'ordem e progresso', que então passou a ser 'desenvolvimento e segurança'. Politicamente, o regime levou aos estertores as últimas veleidades do discurso liberal populista, sufocando, inclusive pela repressão violenta, todas as iniciativas atreladas ao ideário libertário do período anterior, pondo fim ao populismo sob todas as suas expressões. Ao mesmo tempo, o atrelamento da economia nacional ao capitalismo internacional se consolidou definitivamente, mediante uma política de associação e de dependência. A função do Estado nacional se redefine, gerando um Executivo forte e centralizador, com poder de controle político-policial, modernizando e centralizando a administração pública e repelindo brutalmente toda contestação. Trata-se de um regime tecnoburocrático, assumidamente autoritário e repressor. 
Valores proclamados, seja pela ideologia católica, seja pela ideologia liberal, são reenquadrados nas coordenadas da ideologia tecnocrática, que passa a ser o critério de sua validade e sobrevivência no novo contexto social. Suas contribuições só são aproveitadas quando não se contrapõem aos novos interesses, não provocando interferências e questionamentos nos negócios de Estado da nova ordem político-social. Ao mesmo tempo, o governo militar apoiava, incentivava e induzia iniciativas, em todos os campos da vida social, que concretizassem os valores de sua nova política plenamente em sintonia com o capitalismo. Assim, no campo educacional e cultural, favoreceu e incentivou a privatização, uma vez que a educação deve ser entendida e praticada como um serviço, no seio de um mercado livre. A demanda por educação, tão cara às camadas médias da população, deverá ser atendida pela oferta do mercado dos serviços educacionais. Trata-se de uma política de expansão pela privatização. Ademais, o Estado pós-64 tem uma visão instrumentalista da educação, organizada em função do crescimento econômico (Martins, 1981). O conteúdo do ensino deve ser técnico, sem conotação política de cunho crítico. Visa-se à maior produtividade possível, a baixo custo, mediante o preparo de uma mão-deobra numerosa, com qualificação puramente técnica, disciplinada e dócil, adequada ao atendimento das necessidades do sistema econômico. A ideologia tecnocrática do período pratica um autoritarismo disciplinar intrínseco ao processo de engenharia social que deve comandar todos os aspectos da vida da sociedade. Alicerçada epistemologicamente no mesmo cientificismo positivista, que se julga legitimado pela sua eficácia tecnológica, opera a modernização da sociedade pelo uso da sofisticação técnico-informacional, ao mesmo tempo que, investindo pesado nos meios de comunicação, desenvolve um intenso programa de indústria cultural destinado à formação da opinião pública, banalizando ainda mais os conteúdos do conhecimento disponibilizado para as massas.

Após 25 anos de autoritarismo exacerbado, o regime, no início da década de 1980, começa a dar sinais de exaustão. Devorando seus próprios filhos, não mais satisfazia aos interesses capitalistas que pretendiam se universalizar mundo afora. Considerou-se superada essa fase da imposição tecnocrática, entendendo-se que os 25 anos foram suficientes para aplainar o terreno para uma nova etapa, agora não mais baseada na repressão violenta pela força, mas pela impregnação sutil da subjetivação ideológica por si mesma. Nos últimos trinta anos, o país vivencia então uma nova fase marcada pela implementação da agenda neoliberal, nova proposta do capitalismo internacional. 


\section{Os Desafios da Educação no Contexto da Sociabilidade Neoliberal}

A partir dos anos 1980, o Brasil, como de resto todo o Terceiro Mundo, é instado a inserir-se no novo processo de desenvolvimento econômico e social do capitalismo em expansão. De preferência isso deveria ser feito sem o uso da violência física de regimes repressivos. Ao contrário, deveria acontecer num ambiente político-social de redemocratização. Nessa linha, os grandes agentes desse capitalismo internacional sem pátria especificam, além de cobrar, via mecanismos propriamente econômicos, a adoção de suas práticas produtivas, monetárias e financeiras, comprometendo todos os países por meio de acordos mundiais, passando a exigir também adequações nos campos político e cultural. A meta continua sendo aquela da plena expansão do capitalismo, agora sem concorrências ideológicas significativas e numa perspectiva declarada de globalização. Fala-se então da agenda neoliberal, ou seja, de uma retomada dos princípios do liberalismo clássico, mas com a devida correção de seus desvios humanitários. O que está em pauta é a total liberação das forças do mercado, a quem cabe a efetiva condução da vida das nações e das pessoas. Daí a pregação do livre-comércio, da estabilização macroeconômica e das reformas estruturais necessárias, em todos os países, para que o sistema tenha alcance mundial e possa funcionar adequadamente. Opera-se então severa crítica ao Estado do Bem-Estar Social, propondo-se um estado mínimo, em seu papel e funções. A iniciativa política deve dar prioridade à iniciativa econômica dos agentes privados. Graças às impressionantes inovações tecnológicas, mormente na esfera da informática, mudam-se igualmente as relações industriais, o sistema do trabalho e o gerenciamento da produção. Os mercados financeiros são liberados e expandidos. Os Estados nacionais tornam-se reféns das políticas internacionais do grande capital. A política interna dos países, por sua vez, é forçada a esse ajuste econômico, impondo a queda dos salários reais, o crescimento do desemprego estrutural, a estatização da dívida externa e a elevação da taxa de juros. Isso implica também a ruptura do esquema de financiamento do setor público (Ianni, 2004; Lombardi, Saviani \& Sanfelice, 2004).

Assim como nas fases anteriores, também agora desencadeia-se um processo ideológico para justificar o modelo imposto, apresentando-o como o único capaz de realizar os objetivos emancipatórios da sociedade e, nesse sentido, superando os anteriores. Mais uma vez, tem-se um conjunto articulado de 
valores que são proclamados, mas não realizados. Uma retórica, que não deixa de encontrar apoios estratégicos em formulações teóricas do pensamento pósmoderno, se torna insistentemente presente em todas as frentes do debate social, fazendo sua cerrada defesa. Ao mesmo tempo, por meio da legislação e das medidas programáticas, o governo passa a aplicar políticas públicas que vão efetivando as diretrizes neoliberais, mais uma vez adiando e talvez inviabilizando uma educação que possa ser mediação da libertação, da emancipação e da construção da cidadania. Não sem razão, o ceticismo e a desesperança constituem a conclusão de estudiosos da questão educacional brasileira. Ao falar da escola brasileira, em conclusão a seus estudos históricos sobre a educação escolar, conclui Xavier (2005:291):

Ela parece ser uma instituição, se não dispensável, secundária para o funcionamento da sociedade brasileira, tal como se encontra estruturada. Entretanto, é fundamental, para o controle das insatisfações populares e a neutralização dos movimentos sociais contestatórios e reivindicatórios, alimentar a crença no caráter redentor da educação escolarizada. Daí a ênfase no discurso pedagógico, nos debates e na elaboração de projetos educacionais e a falta de pressa em realizá-los.

Para essa autora, ocorre uma mitificação da escola, mitificação que atua como um dos pilares da doutrina liberal produzida na transição capitalista e que penetrou cedo em nossa sociedade como parte da ideologia do colonialismo. E quanto mais o capitalismo avançou no país, mais se solidificou essa crença. $\mathrm{O}$ poder se concentrava, a riqueza crescia e supostamente não se distribuía porque a expansão da escola não acompanhava o crescimento populacional, ou sua qualidade não atendia às demandas sociais. "A escola não revoluciona ou transforma a sociedade que a produz e à qual serve; ela apenas consolida e maximiza as transformações em curso quando a aparelhamos para tanto" (Xavier, 2005:284).

Essa forma atual de expressão histórica do capitalismo, sob predomínio do capital financeiro, conduzido de acordo com as regras de um neoliberalismo desenfreado, num momento histórico marcado por um irreversível processo de globalização econômica e cultural, produz um cenário existencial em que as referências ético-políticas perdem sua força na orientação do comportamento das pessoas, trazendo descrédito e desqualificação para a educação. Ao mesmo tempo que, pelas regras da condução da vida econômica e social, instaura um quadro de grande injustiça social, sonegando para a maioria das pessoas as 
condições objetivas mínimas para uma subsistência num patamar básico de qualidade de vida, interfere profundamente na constituição da subjetividade, no processo de subjetivação, manipulando e desestabilizando valores e critérios. Prevalece um espírito de niilismo axiológico, de esvaziamento de todos os valores, de fim das utopias e metanarrativas e da esperança de um futuro melhor, de incapacidade de construir projetos. A eficiência e a produtividade são os únicos critérios válidos. Com bem sintetiza Goergen, "generaliza-se nesse processo para toda a cultura um aspecto da ordem econômica: a eficiência tornase padrão do bom comportamento exigido pela sociedade" (Lombardi \& Goergen, 2005:3).

Configura-se então uma sociabilidade típica desse contexto neoliberal, que se constitui atrelada a profundas mudanças provocadas pelas injunções dessa etapa da economia capitalista na esfera do trabalho, da cidadania e da cultura. Desse modo, constata-se a ocorrência de situações de degradação, no mundo técnico e produtivo do trabalho; de opressão, na esfera da vida social; e de alienação, no universo cultural. Essas condições manifestam-se, em que pesem as alegações em contrário de variados discursos, como profundamente adversas à formação humana, o que tem levado a um crescente descrédito quanto ao papel e à relevância da educação, como processo intencional e sistemático.

Nesse contexto da história real, a educação é interpelada pela dura determinação dessa realidade, no que diz respeito às condições objetivas da existência. Numa profunda inserção histórico-social, a educação é serva da história. Aqui se paga tributo a nossa condição existencial de seres encarnados e, como tais, profundamente predeterminados - esfera dos a priori existenciais. Uma lógica perversa compromete o esforço da humanização. São adversas as condições para se assegurar a qualidade necessária para a educação. Em que pese a existência, nas esferas do Estado brasileiro, de um discurso muito elogioso e favorável à educação, a prática real da sociedade política e das forças econômicas desse atual estágio histórico não corresponde ao conteúdo de seu discurso. Esse discurso se pauta em princípios e valores elevados, mas que não são sustentados nas condições objetivas para sua realização histórica no plano da realidade social.

No plano da subjetividade, utilizando-se de diferentes modalidades de intervenções ideológicas, particularmente através dos meios de comunicação, o sistema atua fortemente no processo da subjetivação humana. Numa frente, opera a subversão do desejo, deturpando a significação do prazer, não se inves- 
tindo adequadamente no aprimoramento da sensibilidade estética. Açulam-se os corpos no sentido de fazer deles fogueiras insaciáveis de prazer que jamais será satisfeito. Ocorre total regressão do estético. Embora prometa a felicidade, não gera condições para sua efetiva realização por todas as pessoas. Subverte também a vontade, impedindo o exercício de sua liberdade, não deixando que o homem pratique sua condição de igualdade: não investe na formação do cidadão, ou seja, aquele que pode agir livremente na sociedade de iguais. Propaga a idéia de uma democracia puramente formal. Não tem por meta o cidadão, mas o contribuinte, o socícola, aquele que habita o locus social mas não compartilha efetivamente de sua constituição, não compartilha das decisões que instauram o processo político-social. No fundo mantém-se a servidão... que até se torna voluntária... Toda essa pedagogia, em vez de levar os sujeitos a entenderse no mundo, mistifica o mundo, manipulando-o para produzir a ilusão da felicidade. Prosperidade prometida mas nunca realizada. Leva ao individualismo egoísta e narcísico, simulacro do sujeito autônomo e livre.

Essa pedagogia subverte ainda a prática do conhecimento, eliminando o seu processamento como construção dos objetos que são conhecidos. Torna-se mero produto e não mais processo, experiência de criatividade, de criticidade e de competência. É literalmente tecnicizado, objetivado, empacotado. A própria ciência é vista como conhecimento eminentemente técnico, o que vem a ser um conceito autocontraditório. Todas as demais formas de saber são desqualificadas. O ceticismo e o relativismo generalizados se impõem, sob alegação de seus compromissos com metanarrativas infundadas.

Nesse contexto, prospera uma ética hedonista baseada no individualismo, de traço narcísico, que vê o homem como se fosse um átomo solto, vivendo em torno de si mesmo, numa sensibilidade ligada apenas ao espetáculo. Puro culto ao prazer que se pretende alcançar pelo consumo compulsivo e desregrado dos bens do mercado. Essa lógica fundada na exacerbada valorização de uma suposta autonomia e suficiência do sujeito individual, no apelo ao consumo desenfreado, compromete o reconhecimento e a reafirmação dos valores universais da igualdade, da justiça e da eqüidade, referências necessárias para uma concepção mais consistente da humanidade, alicerçada no valor básico da dignidade humana.

Coagida pela pressão das determinações objetivas, de um lado, e pelas interferências subjetivas, de outro, a educação é presa fácil do enviesamento ideológico, que manipula as intenções e obscurece os caminhos, confundindo 
objetivos com interesses. Tal situação aumenta e agrava o desafio que a educação enfrenta em sua dialética tarefa de, simultânea e contraditoriamente, inserir os sujeitos educandos nas malhas culturais de sua sociedade e de levá-los a criticar e a superar essa inserção; assim como de fazer um investimento na conformação das pessoas a sua cultura ao mesmo tempo que precisa levá-las a se tornarem agentes da transformação dessa cultura.

Como a educação tem papel fundamental no processo de subjetivação, embora não seja ela o único vetor desse processo, já que essa subjetivação se dá também por outras vias, seja no âmbito da vivência familiar, seja pelos meios de comunicação de massa, seja ainda por interações informais das pessoas no seio da sociedade civil, ela sofre o impacto dessas forças geradas no bojo da dinâmica da vida social e cultural do capitalismo contemporâneo.

\section{O Horizonte do COMPROMISSO ÉTICO-PolítICO DA}

\section{EDUCAÇÃO: EM BUSCA DE UMA NOVA SOCIABILIDADE}

No contraponto dessa situação de degradação, de opressão e de alienação, a educação é interpelada pela utopia, ou seja, por um télos que acena para uma responsabilidade histórica de construção de uma nova sociedade também mediante a construção de uma nova sociabilidade. Isso decorre da condição dos homens como sendo também seres teleológicos, dispondo da necessidade e da capacidade de estabelecer fins para sua ação. É isso que ocorre com a educação; ela precisa ter intencionalidades, buscar a realização de fins previamente estabelecidos.

Levando em conta o seu papel no processo de subjetivação e tendo em vista que o conhecimento é a única ferramenta que cabe ao educador utilizar para enfrentar esses desafios, há que se entender a educação como processo que faz a mediação entre os seus resultados e as práticas reais, pelas quais os brasileiros devem conduzir sua história. Assim, cabe à educação ter em seu horizonte três objetivos intrínsecos:

1) Desenvolver ao máximo o conhecimento científico e tecnológico em todos os campos e dimensões; superar o amadorismo e apropriar-se da ciência e da tecnologia disponíveis para alicerçar o trabalho de intervenção na realidade natural e social. 
2) Desenvolver ao máximo a sensibilidade ética e estética buscando delinear o télos da educação com sensibilidade profunda à condição humana; sentir a razão de ser da existência e a pulsação da vida.

3) Desenvolver ao máximo sua racionalidade filosófica numa dupla direção: numa frente, esclarecer epistemicamente o sentido da existência, e, noutra, afastar o ofuscamento ideológico dos vários discursos; construir uma contra-ideologia como ideologia universalizante que apresenta os produtos do conhecimento para atender aos interesses da totalidade dos homens.

Pela sua própria natureza, a educação tende a atuar como força de conformação social, mas precisa atuar também como força de transformação social. A conformação nasce da necessidade de conservação da memória cultural da espécie, força centrípeta, apelo da imanência, enquanto que a transformação, força centrífuga, apelo da transcendência, busca um avanço, a criação do novo, gerando elementos que respondam pela criação de nova cultura.

A educação conforma os indivíduos, inserindo-os na sua sociedade, fazendo-os compartilhar dos costumes morais e de todos os demais padrões culturais, com o fito de preservar a memória cultural; porém, ao transformar, impele à criação de nova cultura, reavaliando seus estágios anteriores de subjetivação. Cabe-lhe questionar os estágios vigentes de uma perspectiva crítica, desconstruindo para reconstruir, pois o que não se transforma se petrifica.

É pela mediação de sua consciência subjetiva que o homem pode intencionar sua prática, pois essa consciência é capaz de elaborar sentidos e de se sensibilizar a valores. Assim, ao agir, o homem está sempre se referenciando a conceitos e valores, de tal modo que todos os aspectos da realidade envolvidos com sua experiência, todas as situações que vive e todas as relações que estabelece são atravessados por um coeficiente de atribuição de significados, por um sentido, por uma intencionalidade, feita de uma referência simultaneamente conceitual e valorativa. Desse modo, as coisas e situações relacionam-se com nossos interesses e necessidades, por meio da experiência dessa subjetividade valorativa, atendendo, de um modo ou de outro, a uma sensibilidade que temos, tão arraigada quanto aquela que nos permite representar as coisas e conhecêlas mediante os conceitos.

Com efeito, a ética só pode ser estabelecida por meio de um processo permanente de decifração do sentido da existência humana, tal como ela se 
desdobra no tecido social e no tempo histórico, não mais partindo de um quadro atemporal de valores, abstratamente concebidos e idealizados. Essa investigação é inteiramente compromissada com as mediações históricas da existência humana, não tendo mais a ver apenas com ideais abstratos, mas também com referências econômicas, políticas, sociais, culturais. Nenhuma ação que provoque a degradação do homem em suas relações com a natureza, que reforce sua opressão pelas relações sociais, ou que consolide a alienação subjetiva, pode ser considerada moralmente boa, válida e legítima.

É por isso que, na perspectiva do modo atual de se conceber a ética, ela se encontra profundamente entrelaçada com a política, concebida esta como a área de apreensão e aplicação dos valores que atravessam as relações sociais que interligam os indivíduos entre si. Mas a política, por sua vez, está intimamente vinculada à ética, pelo fato de não poder se ater exclusivamente a critérios técnico-funcionais, caso em que se transformaria numa nova forma de determinismo extrínseco ao homem, à sua humanidade. Isso quer dizer que os valores pessoais não são apenas valores individuais; eles são simultaneamente valores sociais, pois a pessoa só é especificamente um ser humano quando sua existência realiza-se nos dois registros valorativos. Assim, a avaliação ética de uma ação não se refere apenas a uma valoração individual do sujeito; é preciso referi-la igualmente ao índice do coletivo.

É assim que, à luz das contribuições mais críticas da filosofia da educação da atualidade, impõe-se atribuir à educação, como sua tarefa essencial, a construção da cidadania. A educação já se deu outrora como objetivo a busca da perfeição humana, idealizada como realização da essência do homem, de sua natureza; mais recentemente, essa perfeição foi concebida como plenitude da vida orgânica, como saúde física e mental. Hoje, no entanto, as finalidades perseguidas pela educação dizem respeito à instauração e à consolidação da condição de cidadania, pensada como qualidade específica da existência concreta dos homens, lembrando-se sempre que essa é uma teleologia historicamente situada.

Com efeito, a educação só se compreende e se legitima enquanto for uma das formas de mediação das mediações existenciais da vida humana, se for efetivo investimento em busca das condições do trabalho, da sociabilidade e da cultura simbólica. Portanto, só se legitima como mediação para a construção da cidadania. Por isso, enquanto investe, do lado do sujeito pessoal, na construção dessa condição de cidadania, do lado dos sujeitos sociais estará investindo na 
construção da democracia, que é a qualidade da sociedade que assegura a todos os seus integrantes a efetivação coletiva dessas mediações.

À educação cabe, como prática intencionalizada, investir nas forças emancipatórias dessas mediações, num procedimento contínuo e simultâneo de denúncia, desmascaramento e superação de sua inércia de entropia, bem como de anúncio e instauração de formas solidárias de ação histórica, buscando contribuir, com base em sua própria especificidade, para a construção de uma humanidade renovada. Ela deve ser assumida como prática simultaneamente técnica e política, atravessada por uma intencionalidade teórica, fecundada pela significação simbólica, mediando a integração dos sujeitos educandos nesse tríplice universo das mediações existenciais: no universo do trabalho, da produção material, das relações econômicas; no universo das mediações institucionais da vida social, lugar das relações políticas, esfera do poder; no universo da cultura simbólica, lugar da experiência da identidade subjetiva, esfera das relações intencionais. Em suma, a educação só se legitima intencionalizando a prática histórica dos homens...

Com efeito, se se espera que a educação seja de fato um processo de humanização, é preciso que ela se torne mediação que viabilize, que invista na implementação dessas mediações mais básicas, contribuindo para que elas se efetivem em suas condições objetivas reais. Ora, esse processo não é automático, não é decorrência mecânica da vida da espécie. É verdade que ao superar a transitividade do instinto e, com ela, a univocidade das respostas às situações, a espécie humana ganha em flexibilidade, mas simultaneamente torna-se vítima fácil das forças alienantes, uma vez que todas as mediações são ambivalentes: ao mesmo tempo que constituem o lugar da personalização, constituem igualmente o lugar da desumanização, da despersonalização. Assim, a vida individual, a vida em sociedade, o trabalho, as formas culturais, as vivências subjetivas, podem estar levando não a uma forma mais adequada de existência, da perspectiva humana, mas antes a formas de despersonalização individual e coletiva, ao império da alienação. Sempre é bom não perdermos de vista a idéia de que o trabalho pode degradar o homem, a vida social pode oprimi-lo e a cultura pode aliená-lo, ideologizando-o...

É por isso que, ao lado do investimento na transmissão aos educandos dos conhecimentos científicos e técnicos, impõe-se garantir que a educação seja mediação da percepção das relações situacionais, que ela lhes possibilite a apreensão das intrincadas redes políticas da realidade social, pois só a partir daí eles 
poderão se dar conta também do significado de suas atividades técnicas e culturais. Cabe ainda à educação, no plano da intencionalidade da consciência, desvendar os mascaramentos ideológicos de sua própria atividade, evitando assim que ela se instaure como mera força de reprodução social e se torne força de transformação da sociedade, contribuindo para extirpar do tecido desta todos os focos da alienação (Althusser, s.d.; Gramsci, 1968; Severino, 1986).

A análise crítica da experiência histórica da educação brasileira mostra que ela desempenhou, em cada um dos seus cenários temporais, a função de reprodução da ideologia, mediante o que contribuiu para a reprodução das relações sociais vigentes a cada momento. Mas isso não compromete seu outro papel fundamental, que é aquele de transformar essas relações sociais, contribuindo para a elaboração de uma contra-ideologia que possa identificar-se com os interesses e objetivos da maioria da população, fazendo com que os benefícios do conhecimento possam atingir o universo da comunidade humana a que se destina.

Esse compromisso ético-político da educação para com a condução do destino da sociedade não pode, no entanto, ser concebido nos parâmetros da ética essencialista, de fundo metafísico, ou de uma ética funcionalista, de fundo fenomenista. Trata-se de entender sua concepção e prática com base num enfoque praxista. Isso decorre de um modo igualmente novo de pensar o homem. Embora continue sendo entendido como ser natural e dotado de uma identidade subjetiva, que lhe permite projetar e antever suas ações, ele não é visto mais nem como um ser totalmente determinado nem como um ser inteiramente livre. Ele é simultaneamente determinado e livre. Sua ação é sempre um compromisso, em equilíbrio instável entre as injunções impostas pela sua condição de ser natural e a autonomia de sujeito capaz de intencionalizar suas ações, a partir da atividade de sua consciência.

Por práxis, entende-se a prática real do homem, atravessada pela intencionalização subjetiva, ou seja, pela reflexão epistêmica elucidativa e esclarecedora, que delineia os fins e o sentido dessa ação.

O que está em pauta, pois, na reflexão filosófica contemporânea, é a radical historicidade humana. $\mathrm{O}$ homem concebido como ser histórico perde tanto sua fusão com a totalidade metafísica como com a natureza física do mundo. Desse ponto de vista, ele só é especificamente humano quando, em que pesem suas amarras ao mundo objetivo, é capaz de ir construindo-se efetivamente mediante sua ação real. Ora, a ética só tem a ver com sua dimensão especificamente humana, e é nessa especificidade que ela pode encontrar suas referências. 
Esse é o sentido da historicidade da existência humana, ou seja, o homem não é a mera expressão de uma essência metafísica predeterminada, nem o mero resultado de um processo de transformações naturais que estaria em evolução. Ao contrário, naquilo em que o faz especificamente humano, o homem é um ser em permanente processo de construção, em ininterrupto devir. Nunca está pronto e acabado, nem no plano individual, nem no plano coletivo, como espécie. Por sobre um lastro de uma natureza físico-biológica prévia, mas que é pré-humana, compartilhada com todos os demais seres vivos, ele vai se transformando e se reconstruindo como ser especificamente humano, como ser 'cultural'. E isso não apenas na linha de um necessário aprimoramento, de um aperfeiçoamento contínuo ou de progresso. Ao contrário, essas mudanças transformativas, decorrentes de sua prática, podem até ser regressivas, nem sempre sinalizando para uma eventual direção de aprimoramento de nosso modo de ser. O que é importante observar é que seu modo de ser vai se constituindo por aquilo que ele efetivamente faz; é sua ação que o constitui, e não seus desejos, seus pensamentos ou suas teorias...

Assim, a ética contemporânea entende que o sujeito humano se encontra sob as injunções de sua realidade natural e histórico-social, que até certo ponto o conduz, determinando seu comportamento, mas que é também constituída por ele, por meio de sua prática efetiva. Ele não é visto mais como um sujeito substancial, soberano e absolutamente livre, nem como um sujeito empírico puramente natural. Existe concretamente nos dois registros, na medida mesma em que é um sujeito histórico-social, um sujeito cultural. É uma entidade natural histórica, determinada pelas condições objetivas de sua existência, ao mesmo tempo que atua sobre elas por meio de sua práxis.

\section{A Necessidade do Espaço Público para um Projeto Educacional Comprometido com a Emancipação Humana: a escola pública e a CIDADANIA}

O ético-político incorpora a sensibilidade aos valores da convivência social, da condição coletiva das pessoas. A relação, a inter-relação, a dependência recíproca entre as pessoas, é também um valor ético - a eticidade que se apóia na dignidade humana. Essa dignidade não se referencia apenas à existência social, mas também à co-existência social. 
É a partir dessa exigência que se pode compreender a importância da escola para a construção da cidadania. Com efeito, para que a prática educativa real seja uma práxis, é preciso que ela se dê no âmbito de um projeto. A escola é o lugar institucional de um projeto educacional. Isso quer dizer que ela deve instaurar-se como espaço-tempo, como instância social que sirva de base mediadora e articuladora dos outros dois projetos que têm a ver com o agir humano: de um lado, o projeto político da sociedade e, de outro, os projetos pessoais dos sujeitos envolvidos na educação.

Todo projeto implica uma intencionalidade, assim como suas condições reais, objetivas, de concretização, já que a existência dos homens se dá sempre no duplo registro da objetividade/subjetividade, de modo que estão sempre lidando com uma objetividade subjetivada e com uma subjetividade objetivada.

Configura-se aqui a complexa e intrincada questão das relações do processo educativo com o processo social que o envolve por todos os lados. É o que vem sendo apresentado sob o enfoque da teoria do reprodutivismo da educação, segundo a qual a escola nada mais faria do que reproduzir as relações de dominação presentes no tecido social na medida em que, como instância que lida com os instrumentos simbólicos, reproduziria os valores hegemônicos da sociedade, inculcando-os nas novas gerações. A escola é vista então como privilegiado aparelho ideológico do Estado que, por sua vez, não é um representante dos interesses universais da sociedade, mas tão-somente de grupos privilegiados e, conseqüentemente, dominantes.

Reapresenta-se então a questão da dialética objetividade/subjetividade. Em se tratando de processo que lida fundamentalmente com ferramentas simbólicas, a educação é ambígua, ambivalente, uma vez que a subjetividade é lugar privilegiado de alienação. Trata-se ainda de múltiplas subjetividades envolvidas, o que potencializa a força da alienação em relação aos dados da objetividade circundante.

Com efeito, a prática da educação pressupõe mediações subjetivas, a intervenção da subjetividade de todos aqueles que se envolvem no processo. Dessa forma, tanto no plano de suas expressões teóricas como naquele de suas realizações práticas, a educação implica a própria subjetividade e suas produções. Mas a experiência subjetiva é também uma riquíssima experiência das ilusões, dos erros e do falseamento da realidade, ameaçando assim, constantemente, comprometer sua própria atividade. Não sem razão, pois, o exercício da prática educativa exige, da parte dos educadores, uma atenta e constante 
vigilância diante dos riscos da ideologização de sua atividade, seja ela desenvolvida na sala de aula, seja em qualquer outra instância do plano macrossocial do sistema de educação da sociedade.

O procedimento da consciência, no seu desempenho subjetivo, não tem a inflexibilidade mecânica e linear dos instintos. Ao representar e ao avaliar os diversos aspectos da realidade, a consciência facilmente os falseia. A representação simbólica da realidade, que lhe cabia fazer, perde então seu caráter objetivo e se impregna de significações que não mais correspondem à realidade, e a visão elaborada pelo sujeito fica falseada. $\mathrm{Na}$ sua atividade subjetiva, a consciência deveria visar e dirigir-se à realidade objetiva, atendo-se a ela. No entanto, quanto mais autônoma e livre em relação à transitividade dos instintos, mais frágil se torna em relação à objetividade e mais suscetível de sofrer interferências perturbadoras. À consciência subjetiva pode ocorrer de se projetar numa objetividade não-real, apenas projetada, imaginada, ideada. É como se estivesse imaginando um mundo inventado, invertido. E assim a consciência, alienandose em relação à realidade objetiva, constrói conteúdos representativos com os quais pretende explicar e avaliar os vários aspectos da realidade e que apresenta como sendo verdadeiros e válidos, aptos não só a explicá-los mas também a legitimá-los. Porém, alienada, a consciência não se dá conta de que tais conteúdos nem sempre estão se referindo adequadamente ao objeto. $\mathrm{Na}$ verdade, tais conteúdos - idéias, representações, conceitos, valores - são ideológicos, ou seja, têm obviamente um sentido, um significado, mas descolado do real objetivo, pois referem-se de fato a um outro aspecto da realidade que, no entanto, fica oculto e camuflado. Ocorre um falseamento da própria apreensão pela consciência, um desvirtuamento de seu proceder, decorrente sobretudo da pressão de interesses sociais que, intervindo na valoração da própria subjetividade, altera a relação de significação das representações.

Esses interesses/valores que intervêm e interferem na atividade cognoscitiva e valorativa da consciência nascem das relações sociais de poder, das relações políticas, que tecem a trama da sociedade. É para legitimar determinadas relações de poder que a consciência apresenta como objetivas, universais e necessárias, portanto supostamente verdadeiras, algumas representações que, na realidade social, referem-se de fato a interesses de grupos particulares, em geral grupos dominantes, detentores do poder no interior da sociedade.

A força do processo de ideologização é, sem dúvida, um dos maiores percalços da prática educativa, porque ela atua no seu âmago. Mas a possibilida- 
de da interferência da ideologia não invalida nem inviabiliza a escola. O simples fato do reconhecimento do poder ideologizador da educação testemunha igualmente o valor da subjetividade, seu poder de doação de significações. O que cabe, no entanto, à escola, na sua autoconstituição como centro de um projeto educacional, é ter presente essa ambivalência de sua própria condição de agência educativa e investir na explicitação e na crítica desses compromissos ideológicos, etapas preliminares para que possa tornar seu projeto elemento que transforma a escola em lugar também de elaboração de um discurso contra-ideológico e, conseqüentemente, de instauração de uma nova consciência social e até mesmo de novas relações sociais. A educação pode se tornar também uma força transformadora do social, atuando portanto contra-ideologicamente.

Educar contra-ideologicamente é utilizar, com a devida competência e criticidade, as ferramentas do conhecimento, as únicas de que efetivamente o homem dispõe para dar sentido às práticas mediadoras de sua existência real. Por mais ambíguos e fragilizados que sejam esses recursos da subjetividade, eles são instrumentos capazes de explicitar verdades históricas e de significar, com um mínimo de fidelidade, a realidade objetiva em que o homem desenvolve sua história. O que se impõe é a adequada exploração do conhecimento, poderosa estratégia do homem para se nortear no espaço social e no tempo histórico. Daí a relevância do conhecimento em suas dimensões científica e filosófica, âmbitos nos quais há a possibilidade efetiva de se assegurar a competência e a criticidade necessárias no caso de utilização de nossa subjetividade.

A escola se caracteriza, pois, como a institucionalização das mediações reais para que uma intencionalidade possa tornar-se efetiva, concreta, histórica, para que os objetivos intencionalizados não fiquem apenas no plano ideal, mas ganhem forma real.

Assim sendo, a escola se dá como lugar do entrecruzamento do projeto político coletivo da sociedade com os projetos pessoais e existenciais de educandos e educadores. É ela que viabiliza que as ações pedagógicas dos educadores se tornem educacionais, na medida em que se impregna das finalidades políticas da cidadania que interessa aos educandos. Se, de um lado, a sociedade precisa da ação dos educadores para a concretização de seus fins, de outro os educadores precisam do dimensionamento político do projeto social para que sua ação tenha real significado como mediação da humanização dos educandos. Estes encontram na escola um dos espaços privilegiados para a vivificação e a efetivação de seu projeto. 
A escola se faz necessária para abrigar e mediatizar o projeto educacional, imprescindível para uma sociedade autenticamente moderna. A especificidade do trabalho pedagógico exige uma institucionalização de meios que vinculem educadores e educandos. A escola não pode ser substituída pelos meios de comunicação de massa; toda relação pedagógica depende de um relacionamento humano direto. Toda situação de aprendizagem, para ser educacional, não basta ser tecnicamente operativa; precisa ser pedagógica, ou seja, relacionar pessoas diretamente entre si. Aliás, a fecundidade didática dos meios técnicos já é dependente da incorporação de significados valorativos pessoais.

Para que se possa falar de um projeto impregnado por uma intencionalidade significadora, impõe-se que todas as partes envolvidas na prática educativa de uma escola estejam profundamente integradas na constituição e no vivenciamento dessa intencionalidade. Do mesmo modo que, num campo magnético, todas as partículas do campo estão imantadas, no âmbito de um projeto educacional todas as pessoas envolvidas precisam compartilhar dessa intencionalidade, adequando seus objetivos parciais e particulares ao objetivo abrangente da proposta pedagógica decorrente do projeto educacional. Mas, para tanto, impõe-se que toda a comunidade escolar seja efetivamente envolvida na construção e na explicitação dessa mesma intencionalidade. É um sujeito coletivo que deve instaurá-la; e é nela que se lastreiam a significação e a legitimidade do trabalho em equipe e de toda interdisciplinaridade, tanto no campo teórico como no campo prático.

Ao investir na constituição da cidadania dos indivíduos, a educação escolar está articulando o projeto político da sociedade - que precisa ter seus membros como cidadãos - e os projetos pessoais desses indivíduos que, por sua vez, precisam do espaço social para existir humanamente.

Em sociedades históricas passando por momentos de determinação alienadora, de opressão e de exploração, implementando projeto político voltado para interesses egoísticos de grupos particulares hegemônicos, como é o caso de nossa sociedade brasileira atual, fica ainda mais fragilizada a força da instituição escolar nesse seu trabalho de construção da cidadania, uma vez que o projeto educacional autêntico estaria necessariamente em conflito com o projeto político da sociedade que, ao oprimir a maioria dos indivíduos que a integram, compromete até mesmo a possibilidade de o educador construir seu projeto pessoal. Esbarra-se aí nos limites impostos pela manipulação, pela ex- 
propriação e pela alienação dos seres humanos. Muitas vezes, investir na construção de um projeto educacional é pura prática de resistência.

No entanto, mesmo nesse caso, a escola se torna ainda mais necessária, impondo-se um investimento sistemático com vistas a sua sustentação e ao desenvolvimento de um projeto educacional eminentemente contra-ideológico, ou seja, desmascarando, denunciando, criticando esse projeto político, não se conformando com ele, não o aceitando passivamente. Com as armas fornecidas pelo conhecimento, devendo realizar seu trabalho educacional no contexto de uma sociedade opressiva, os educadores precisam pautar-se num público de educação, concebido e articulado em instituições que gerem um espaço público aberto à totalidade social, sem qualquer tipo de restrição.

Após duas décadas sob a tutela de um Estado autoritário e autocrático, no qual a dimensão pública se reduzira à expressão meramente tecnoburocrática do estatal, mergulhada na voracidade consumista do momento neoliberal, o sentido do público acaba deslizando para uma mera identificação do civil ao mercadológico, ou seja, a sociedade civil não é mais a comunidade dos cidadãos, mas a comunidade dos produtores e dos consumidores em relação de mercado. Toda a vida social passa a ser medida e marcada pelo compasso das transações comerciais, do que não escapa nenhum setor da cultura, nem mesmo a educação. O dilema que vivemos hoje se expressa exatamente por essa ambigüidade, pela qual a dimensão pública se esvazia, impondo a minimização do Estado na condução das políticas sociais, que ficam dependentes apenas das leis do mercado, tido como dinâmica própria da esfera do privado. Daí o ímpeto privatizante que varre a sociedade e a cultura do Brasil nas últimas três décadas, sob o sopro incessante e denso dos ventos ideológicos do neoliberalismo. A oferta de educação, assim como dos demais chamados serviços públicos, é um dentre outros empreendimentos econômico-financeiros a serem conduzidos nos termos das implacáveis leis do mercado.

Em todas as situações de ambigüidade que as atravessam, as categorias de público e de privado padecem de uma limitação congênita que compromete sua validade político-educacional, impondo aos atuais teóricos e práticos da educação uma inconclusa tarefa de redimensioná-los com vistas a assegurar-lhe eficácia e legitimidade. Para tanto, é preciso ter presente a historicidade da construção dessas categorias. Assim, é necessário reconhecer a procedência da universalidade do bem comum, mas que deve ser entendida como uma possibilidade histórica a ser realizada no fluxo do tempo. Impõe-se ainda reconhecer a 
rica contribuição do iluminismo liberal na construção do estado de direito como tentativa de instauração de uma determinada ordenação do social. Como se sabe, o direito nasceu na civilização humana como forma de organizar as relações entre os homens, de modo a garantir um mínimo de simetria nessas relações, assegurando assim a justiça, ou seja, que um mínimo de eqüidade nelas reinasse. No entanto, tão logo conseguiu apreender-se como uma coletividade a que se impunha uma convivência em comum, a humanidade percebeu, com base em sua experiência empírica, que o tecido social não se constituía como uma teia de membros iguais. O tecido social era todo marcado por forte hierarquização estratificada, em que ocorre grande desequilíbrio das forças em presença, em que alguns indivíduos ou grupos não só se opunham uns aos outros como dominavam os indivíduos ou grupos mais fracos. Uma intensa luta de interesses colocava esses elementos em situação de conflito, geradora de muitas formas de violência e de opressão.

É íntima a aproximação que os teóricos modernos fizeram entre democracia e o caráter público da atuação do Estado (por isso mesmo, deveria ser preferencialmente uma res publica), mediante a qual poderia assegurar a todos os integrantes da sociedade o acesso e o usufruto dos bens humanos, garantindo a todos, com o máximo de eqüidade, o compartilhamento do bem comum. No entanto, essa expectativa tende a frustrar-se continuamente, tal a fragilidade do direito em nossa sociedade. A experiência histórica da sociedade brasileira foi e continua sendo marcada pela realidade brutal da violência, do autoritarismo, da dominação, da injustiça, da discriminação, da exclusão, enfim, da falta do direito. É assim que o nosso não tem sido um Estado de direito; ele sempre foi, sob as mais variadas formas, um Estado de fato, no qual as decisões são tomadas e implementadas sob o império da força e da dominação. Não é um agenciador dos interesses coletivos e muito menos dos interesses dos segmentos mais fracos da população que constitui sua sociedade civil. Na verdade, as relações de poder no interior da sociedade brasileira continuam moldadas nas relações de tipo escravocrático que a fundaram, aquelas relações do tipo 'casa-grande e senzala', metáfora que é, na verdade, descrição científica.

Desse modo, o direito acaba desvirtuado pelo seu próprio enviesamento ideológico. Se, de um lado, ele é visto pelos que dele dependem como meio para contar com o usufruto do bem comum, de outro ele é usado por aqueles que dele pouco precisam para salvaguardar seus privilégios. No campo específico da educação, a legislação passa a ser então estratagema ideológico, prome- 
tendo exatamente aquilo que não pretende conceder. Por isso mesmo, na medida em que grupos com interesses diferentes e opostos podem lutar por eles, acabam travando uma luta ideológica, ou seja, buscam servir-se da legislação como um instrumento da garantia desses direitos. Nessa luta sem tréguas, o caráter público da educação vai sendo, cada vez mais, comprometido.

É por isso mesmo que, de acordo com o atual modelo, o processo fundamental da história humana deve ser conduzido pelas forças da própria sociedade civil, e não mais pela administração via aparelho do Estado. Entendese que o motor da vida social é o mercado, e não a administração política. As leis gerais são aquelas da economia do mercado, e não as da economia política. E o mercado se regula por forças concorrenciais, nascidas dos interesses dos indivíduos e grupos, que se 'vetorizam' no interior da própria sociedade civil donde a proposta do Estado mínimo e os elogios à fecundidade da livreiniciativa, à privatização generalizada etc.

Dessa situação decorrem igualmente os profundos equívocos que vêm atravessando a política educacional brasileira das últimas décadas, ao estender a privatização exacerbada e sem critérios também aos assim chamados 'serviços educacionais', atendendo apenas às diretrizes da agenda econômica neoliberal. Trata-se de prática duplamente perversa. De um lado, desconhece a incapacidade econômica da maioria da população brasileira de se integrar no processo produtivo de uma economia de mercado, que pressupõe um patamar mínimo de condições objetivas para que os agentes possam dela participar. Abaixo desse nível, essa participação se situará necessariamente numa esfera de marginalidade econômico-social. De outro lado, a perversidade do sistema se manifesta igualmente no fato da precária qualidade de educação que sobra para a população que dela mais precisa, tanto nas escolas/empresas quanto nas escolas públicas ainda mantidas pelo Estado, ou seja, tal educação ofertada não habilitará essa população a ponto de lhe viabilizar a ruptura do círculo de ferro de sua opressão. Apenas uma elite vinculada aos segmentos dominantes dispõe de uma educação qualificada, sem dúvida alguma capaz de habilitá-a para continuar no exercício da dominação.

O sentido do público é aquele abrangido pelo sentido do bem comum efetivamente universal, ou seja, que garanta ao universo dos sujeitos o direito de usufruir dos bens culturais da educação, sem nenhuma restrição. A questão básica não é a da referência jurídica de manutenção dos subsistemas de ensino, mas a do seu efetivo envolvimento com o objetivo da educação universalizada. 
As instituições particulares de ensino também não podem eximir-se de um comprometimento que leve em conta um projeto político-social identificado com as necessidades objetivas do todo da população. O equívoco radical está em se entenderem e, sobretudo, em se vivenciarem apenas como instâncias do mercado, em que os bens simbólicos da cultura transformam-se em bens puramente econômicos, esvaziados de todo conteúdo humano e humanizador.

\section{CONSIDERAÇÕES FINAIS}

De todas essas considerações, impõe-se concluir que, na atual situação histórico-social brasileira, só mesmo um sistema universalizado de ensino estará em condições de enfrentar o desafio da construção da cidadania universalização esta absolutamente imprescindível para tanto. Se é verdade que possam existir, hipoteticamente, variadas modalidades de mediações da educação, historicamente é também verdadeiro que a escola se revela como sua mediação potencialmente mais eficaz para a universalização da educação. Isso implica, sem nenhuma dúvida, a constituição de um grande e qualificado sistema público de ensino.

A identidade específica da prática educativa, a ser implementada por todos aqueles que têm um projeto civilizatório para o enfrentamento dos desafios históricos lançados na atualidade, se encontra no tripé formado pelo domínio do saber teórico, pela apropriação da habilitação técnica e pela sensibilidade ao caráter político das relações sociais. Mas essas três dimensões só se consolidam se soldadas, se articuladas pela dimensão ética. O envolvimento pessoal e a sensibilidade ética dos educadores estão radicalmente vinculados a um compromisso com o destino dos homens. É à humanidade que cada um tem que prestar contas. Por isso mesmo é que o maior compromisso ético é ter compromisso com as responsabilidades técnicas e com o engajamento político. Trata-se, pois, para todos os homens, de vincular sua responsabilidade ética à responsabilidade referencial de construção de uma sociedade mais justa, mais eqüitativa - vale dizer, uma sociedade democrática, constituída de cidadãos participantes em condições que garantam a todos os bens naturais, os bens sociais e os bens simbólicos, disponíveis para a sociedade concreta em que vivem, e a que todos têm direito, em decorrência da dignidade humana de cada um.

O respeito e a sensibilidade ao eminente valor representado pela dignidade da pessoa humana não tornam essa postura ética abstrata, idealizada e aliena- 
da. Ao contrário, exigem o aguçamento da sensibilidade às condições históricas e concretas de nossa existência - afinal, suas únicas mediações reais. Esse aguçamento exige, por sua vez, o pleno compromisso de aplicação do uso da única ferramenta para a orientação da existência humana: o conhecimento que precisa tornar-se, então, competente, criativo e crítico. A mais radical exigência ética que se faz manifesta, neste quadrante de nossa história, para todos os sujeitos envolvidos na e pela educação é, sem nenhuma dúvida, o compromisso de aplicação do conhecimento na construção da cidadania.

\section{REFERÊNCIAS BIBLIOGRÁfICAS}

ALTHUSSER, L. Ideologia e Aparelhos Ideológicos de Estado. Lisboa, São Paulo: Presença, Martins Fontes, s.d.

BRESSER PEREIRA, L. C. Desenvolvimento e Crise no Brasil: 1939-1967. Rio de Janeiro: Zahar, 1968.

FERNANDES, F. A Revolução Burguesa no Brasil: ensaio de interpretação sociológica. Rio de Janeiro: Zahar, 1975.

GRAMSCI, A. A Concep̧ção Dialética da História. Rio de Janeiro: Civilização Brasileira, 1968

IANNI, O. O cidadão do mundo. In: LOMBARDI, J. C.; SAVIANI, D. \& SANFELICE, J. L. (Orgs.). Capitalismo, Trabalho e Educação. 2.ed. Campinas: Autores Associados, 2004. p.27-34.

IBGE. PNAD: Relatório 2004. Brasília: IBGE, 2005.

LOMBARDI, J. C. \& GOERGEN, P. (Orgs.). Ética e Educação: reflexões filosóficas e históricas. Campinas: Autores Associados, 2005.

LOMBARDI, J. C.; SAVIANI, D. \& SANFELICE, J. L. (Orgs.). Capitalismo, Trabalho e Educação. 2.ed. Campinas: Autores Associados, 2004.

MARTINS, C. B. Ensino Privado, um Retrato sem Retoques. São Paulo: Global, 1981.

SEVERINO, A. J. Educação, Ideologia e Contra-Ideologia. São Paulo: EPU, 1986.

SEVERINO, A. J. Educação, Sujeito e História. São Paulo: Olho d'Água, 2001.

XAVIER, M. E. S. P. Políticas educacionais, modelos pedagógicos e movimentos sociais. In: MIGUEL, M. E. B. \& CORRÊA, L. T. (Orgs.). A Educação Escolar em Perspectiva Histórica. Campinas: Autores Associados, Capes, 2005. p.283291. (Memória da educação) 


$$
\begin{gathered}
\text { Formato: } 16 \times 23 \mathrm{~cm} \\
\text { Tipologia: Garamond e Engravers } \\
\text { Papel: Pólen Bold } 90 \mathrm{~g} / \mathrm{m}^{2}(\text { miolo) } \\
\text { Cartão supremo } 250 \mathrm{~g} / \mathrm{m}^{2} \text { (capa) } \\
\text { Fotolito: Graftipo Gráfica e Editora Ltda.(capa) } \\
\text { Fotolitos: Laser vegetal (miolo) } \\
\text { Reimpressão e acabamento: Editora e Papéis Nova Aliança } \\
\text { Rio de Janeiro, julho de } 2014
\end{gathered}
$$

Não encontrando nossos títulos em livrarias, contactar a EDITORA Fiocruz: Av. Brasil, 4036 - Térreo - sala 112 - Manguinhos - 21040-361

Rio de Janeiro - RJ.

Tel.: (21) 3882-9039 e 3882-9041 - Telefax: (21) 3882-9006 www.fiocruz.br/editora editora@fiocruz.br 